\title{
Conservative strategy in patients with non-ST-segment elevation acute coronary syndromes
}

Strategia zachowawcza w leczeniu ostrego zespołu wieńcowego bez uniesienia odcinka ST

\author{
Jarosław Zalewski ${ }^{1,2}$, Krzysztof Nycz², Tadeusz Przewłocki³ ${ }^{3}$ Marek Andres², Monika Durak², Piotr Lech², \\ Piotr Pieniążek ${ }^{3}$ Krzysztof Żmudka ${ }^{1}$
}

1Department of Hemodynamics and Angiocardiography, Institute of Cardiology, Jagiellonian University, Krakow, Poland

${ }^{2}$ Cardiovascular Intervention Center, John Paul II Hospital, Krakow, Poland

${ }^{3}$ Department of Cardiovascular Diseases, Institute of Cardiology, Jagiellonian University, Krakow, Poland

Post Kardiol Interw 2010; 6, 4 (22): 147-153

DOI: $10.5114 /$ pwki.2010.17627

\begin{abstract}
Background: Clinical outcomes of patients with non-ST-segment elevation acute coronary syndrome (NSTACS) disqualified from an invasive strategy (InvS) remain incompletely understood.

Aim: To investigate short-term results of a conservative strategy (ConS) in a real-life population of patients with NSTACS.

Material and methods: 526 patients with NSTACS were retrospectively analysed. Of these, 335 (63.7\%) patients were initially qualified for the ConS. In the remaining 191 (36.3\%) patients an InvS was applied.

Results: The most frequent reasons for disqualification from an InvS in NSTACS patients were TIMI risk score $\leq 4$ (88.0\%), lack of patient consent (3.9\%) and pulmonary oedema (3.0\%). In the group of InvS, cardiogenic shock on admission was found in 11 (5.8\%) patients. In patients who underwent ConS and InvS 30-day mortality rate was 6.0 and $10.5 \%(p=0.061)$, respectively, whereas 30-day mortality in non-shock patients assigned to InvS was $7.9 \%$ ( $p=0.40$ vs. ConS). During primary hospitalization, 27 ( $8.1 \%$ ) patients with ConS and 7 (3.7\%) with InvS developed symptoms of heart failure (Killip 2-4) ( $p=0.049$ ). In the group of InvS, cardiogenic shock on admission (OR 49.5, 95\% Cl 125-234.2, $p<0.0001$ ) and in patients treated conservatively heart failure during hospitalization (OR 27.4, 95\% Cl 4.8-155.2, $p=0.003$ ) were independent predictors of 30-day mortality (c-statistics 0.70 ).

Conclusions: In NSTACS patients, low risk of complications at baseline was the main reason for disqualification from InvS. The mortality rate within 30 days did not differ significantly between the two therapeutic groups. Symptoms of heart failure during hospitalization were an independent predictor of death within 30 days in NSTACS patients disqualified from InvS.
\end{abstract}

Key words: non-ST-segment elevation acute coronary syndrome, conservative strategy, percutaneous coronary intervention

Streszczenie

Wstęp: Wyniki leczenia pacjentów z ostrym zespołem wieńcowym bez uniesienia odcinka ST (NSTACS) niezakwalifikowanych do leczenia inwazyjnego (InvS) nie są dobrze poznane.

Cel: Ocena wczesnego wyniku klinicznego strategii zachowawczej (ConS) zastosowanej w nieselekcjonowanej grupie pacjentów z NSTACS.

Materiał i metody: Retrospektywnie przeanalizowano 526 pacjentów z NSTACS. Spośród tej grupy 335 (63.7\%) pacjentów zostato pierwotnie zakwalifikowanych do ConS, pozostałych 191 (36.3\%) poddano InvS.

Wyniki: Głównymi czynnikami wykluczającymi z InvS w grupie pacjentów z NSTACS były: stopień ryzyka wg skali TIMI $\leq 4$ (88,0\%), brak zgody pacjenta na interwencję (3,9\%) i obrzęk płuc (3,0\%). Przy przyjęciu 11 (5,8\%) pacjentów poddanych InvS prezentowało objawy wstrząsu kardiogennego. Śmiertelność 30-dniowa wśród pacjentów z NSTACS w grupach ConS i InvS wyniosła odpowiednio $6,0 \%$ i 10,5\% ( $p=0,061)$, a wśród chorych bez wstrząsu kardiogennego poddanych InvS 7,9\% ( $p=0,40$ vs ConS). Podczas hospitalizacji u 27 (8,1\%) pacjentów poddanych ConS i 7 (3,7\%) leczonych inwazyjnie rozwinęły się objawy niewydolności serca (klasa 2-4 wg Killipa) ( $p=0,049)$. W grupie pacjentów poddanych InvS objawy wstrząsu kardiogennego przy przyjęciu (OR 49,5, 95\% Cl 125-234,2, p < 0,0001), a w grupie pacjentów poddanych ConS objawy niewydolności serca podczas hospitalizacji (OR 27,4, 95\% Cl 4,8-155,2, $p=0,003$ ) w sposób niezależny determinowały 30-dniową śmiertelność (c-statystyka 0.70).

Corresponding author/Adres do korespondencji:

Jarosław Zalewski MD, Centrum Interwencyjnego Leczenia Chorób Serca i Naczyń, Krakowski Szpital Specjalistyczny im. Jana Pawła II, ul. Prądnicka 80, 31-202 Kraków, tel.: +48 1261435 01, fax: +48 1261430 47, e-mail: jzalewski@szpitaljp2.krakow.pl

Praca wpłynęła 8.08.2010, przyjęta do druku 30.09.2010. 
Wnioski: Najczęstszą przyczyną dyskwalifikacji pacjentów z NSTACS jako kandydatów do leczenia inwazyjnego było wyjściowo oszacowane niskie ryzyko powikłań, a zastosowane kryteria kwalifikacji wiązały się z brakiem istotnej różnicy w 30-dniowej śmiertelności wśród pacjentów poddanych obu strategiom terapeutycznym. Wystąpienie objawów niewydolności serca po kwalifikacji u pacjentów poddanych strategii zachowawczej było niezależnym czynnikiem ryzyka zgonu do 30. dnia.

Słowa kluczowe: ostry zespół wieńcowy bez przetrwałego uniesienia odcinka ST, strategia zachowawcza, przezskórna interwencja wieńcowa

\section{Introduction}

Acute coronary syndrome (ACS) is the most severe and life-threatening clinical manifestation of ischaemic heart disease. Accurate and immediate diagnosis, risk stratification based on the individual clinical situation and adequate therapy for individual patients without time delay are the key points to achieve proper and satisfactory shortand long-term clinical outcomes.

From the clinical point of view it is important to divide the whole spectrum of ACS into two different categories: ST-segment elevation myocardial infarction (STEMI) [1] and non-ST-segment acute coronary syndrome (NSTACS) [2]. While in STEMI patients percutaneous coronary intervention undoubtedly remains the gold standard for coronary blood flow restoration, the recommended treatment strategy for NSTACS subjects still depends on early risk stratification [3-7]. Irrespective of differences in pathophysiology and treatment of choice, 6-month mortality is about $12-13 \%$ and remains comparable in all types of ACS $[3,4]$. At longer observation times patients with non-ST segment elevation myocardial infarction (NSTEMI) are at two-fold higher mortality risk than those with STEMI [5].

The development of new invasive therapeutic options and medicines in combination with a deeper insight into the underlying pathophysiology of ACS requires modification of clinical management algorithms that enable treatment optimization of NSTACS and achievement of better short- [6-8] and long-term clinical outcomes [7, 9]. Algorithms and guidelines for ACS management are based on large, controlled clinical trials that include primarily selected patients differing from ACS patients in everyday clinical practice. Undoubtedly, percutaneous coronary intervention remains the most suitable and effective way of treatment in high risk patients with NSTACS, and its advantages over conservative strategy are widely described [2, 6-9]. However, the real life reasons leading to disqualification from an invasive strategy are varied and do not necessarily reflect the estimated risk in the approved scoring systems.

We sought to investigate both the reasons for disqualification from an invasive strategy and early, inhospital and 30-day mortality in a group of consecutive, unselected NSTACS patients primarily qualified to receive conservative treatment. We also compared these results with NSTACS patients treated invasively at the same time in our department.

\section{Material and methods \\ Study group}

For the period from 1 January to 31 December 2005, physicians from 20 hospitals in Krakow and surrounding towns and emergency ambulance units submitted 1604 patients with ACS for coronary intervention to the duty doctor of the John Paul II Hospital in Krakow. This group consisted of 561 (35\%) NSTACS and 1043 (65\%) STEMI patients. Qualification for invasive treatment of myocardial infarction was performed in accordance with the current European Society of Cardiology guidelines on STEMI [10] and NSTACS [11] management, approved by the Polish Cardiac Society.

In cases of ACS patients without ST-segment elevation, only high risk patients were qualified for the early invasive strategy. For individual risk stratification TIMI Risk Score (TRS) was used. A score of 5 points or higher was the cutoff point for an invasive strategy. Patients with NSTACS and signs of haemodynamic instability or recurrent myocardial ischaemia or life-threatening arrhythmias were also qualified for an invasive strategy, independently of TRS.

During the first telephone contact between being referred to the physician and to the consulting cardiologist, the decision about subsequent therapy in each individual case of NSTACS was made. Disqualification from early invasive therapy was termed a conservative strategy (ConS), and in those cases pharmacotherapy was used. A decision for immediate interventional treatment was termed an invasive strategy (InvS).

Based on the above criteria out of all the 561 NSTACS cases submitted to our department, 191 (34\%) patients were qualified to receive interventional treatment, and the remaining 370 (66\%) patients were to receive conservative therapy alone. After an assessment of all the consultation forms for the year 2005, we asked all collaborating local departments for permission to access the medical records of those who were treated conservatively in those wards. Out of 370 patients with NSTACS qualified for ConS, we were able to assess 335 (90.5\%) cases. Finally, medical records and clinical data from collaborating departments (335 patients) and the catheterization laboratory of our hospital (191 patients) were collected and analysed. An evaluation of in-hospital stay and a 30-day follow-up in 526 cases of NSTACS was conducted. The 30-day mortality rate was estimated on the basis of data received from the Lesser Poland Voivodal Registry of Citizens. The study protocol was approved by the Ethical Committee of the Jagiellonian University Medical College. 


\section{Clinical follow-up}

The primary end-point in this study was death within a 30-day follow-up. Secondary end-points in our retrospective observation were: cardiogenic shock at the time of invasive cardiology consultation, symptoms of heart failure (Killip class 2-4) during the in-hospital period, and delayed referral for coronary angiography or planned invasive diagnostics of coronary arteries within 3 months after index NSTACS.

\section{Statistical analysis}

Statistical analyses were performed with Statistica Version 6 (StatSoft, Inc.) software. Continuous variables were presented as the mean value \pm standard deviation (SD) and analysed using Student's t-test. Categorical variables were expressed as absolute values, percentages or both, and were compared by means of chi-square or Fisher's exact test. Multivariable logistic analysis was performed to obtain independent predictors of the 30-day mortality. The model included independent variables, such as: symptoms of cardiogenic shock at the time of invasive cardiology consultation, heart failure symptoms after the invasive cardiology consultation, applied treatment strategy, age, pharmacotherapy during the in-hospital period, diabetes mellitus, previous myocardial infarction and gender. The c-statistic was calculated to evaluate model discrimination. A $p$ value less than 0.05 was considered statistically significant.

\section{Results}

Study groups characteristics

Patients with NSTACS in both compared groups did not differ with regard to age, gender, arterial hypertension, diabetes, dyslipidaemia or smoking (Tab. 1). Subjects with NSTACS from ConS significantly less likely underwent PCI before the analysed event $(p<0.0001)$ and rarely manifested pulmonary oedema at the time of invasive cardiology consultation ( $p=0.0008)$, in comparison to subjects from the InvS group. All subjects with NSTACS and cardiogenic shock were qualified for InvS and composed $5.8 \%(11 / 191)$ of the group (tab. 1).

The most frequent reason for disqualification (tab. 2) from an InvS in NSTACS patients was TIMI risk score $\leq 4$ at baseline (88.0\%). Rarely was the reason for such a decision lack of the patient's consent for invasive treatment (3.9\%) or pulmonary oedema (3.0\%). Seven (2\%) patients were excluded from InvS due to sudden cardiac arrest with a subsequent dysfunction of the central nervous system, present during the neurological examination.

\section{Treatment}

Patients qualified for InvS significantly more often received a thienopyridine derivative antiplatelet drug in comparison with the Cons group ( $91.4 \%$ vs. $34.5 \%$, $p<0.0001$ ) (tab. 3). Platelet GP IIb/IIla receptor inhibitor was used only in individuals with InvS; 15 subjects from this group received abciximab and 5 eptifibatide. Also heparin was more widely used in patients qualified for InvS than Cons (95.2\% vs. $86.4 \%, p=0.005)$.

Primary coronary angioplasty was performed in $2 / 3$ (127/191) of subjects from the InvS group, 13.1\% (25/191) underwent coronary artery bypass graft surgery, and the remaining 39 subjects (20.4\%) were treated with pharmacotherapy after coronary angiography. In $10.2 \%$ $(13 / 127)$ of cases from the InvS group who underwent primary $\mathrm{PCl}$, a drug-eluting stent was used during the procedure.

Table 1. Baseline characteristics

Tabela 1. Charakterystyka pacjentów

\begin{tabular}{|c|c|c|c|}
\hline & InvS & Cons & $p$ \\
\hline Age (mean \pm SD) [years] & $63.7 \pm 10.4$ & $65.6 \pm 11.3$ & NS \\
\hline Male gender [\% $(n / N)]$ & $67.5(129 / 191)$ & $59.1(198 / 335)$ & NS \\
\hline \multicolumn{4}{|c|}{ Cardiovascular risk factors [\% $(n / N)]$} \\
\hline hypertension & $78.0(149 / 191)$ & $80.0(268 / 335)$ & NS \\
\hline diabetes & $26.2(50 / 191)$ & $29.0(97 / 335)$ & NS \\
\hline dyslipidaemia & $34.5(146 / 191)$ & $42.1(141 / 335)$ & NS \\
\hline smoking & $44.5(85 / 191)$ & $43.6(146 / 335)$ & NS \\
\hline Previous PCI [\% $(n / N)]$ & $9.9(19 / 191)$ & $0.1(3 / 335)$ & $<0.0001$ \\
\hline Previous CABG [\% $(n / N)]$ & $6.3(12 / 191)$ & 0 & - \\
\hline Previous MI [\% $(n / N)]$ & $28.8(55 / 191)$ & $30.1(101 / 335)$ & NS \\
\hline \multicolumn{4}{|c|}{ Killip class at the time of consultation [\% $(n / N)]$} \\
\hline 3 & $10.5(20 / 191)$ & $3.3(11 / 335)$ & 0.0008 \\
\hline 4 & $5.8(11 / 191)$ & 0 & - \\
\hline
\end{tabular}

InvS - invasive strategy, ConS - conservative strategy, $\mathrm{PCl}$ - percutaneous coronary intervention, CABG - coronary artery bypass graft, $\mathrm{MI}$ - myocardial infarction

InvS - strategia inwazyjna, ConS - strategia zachowawcza, $P C l$ - przezskórna interwencja wieńcowa, CABG - pomostowanie aortalno-wieńcowe, $\mathrm{Ml}$ - zawat serca 


\section{Conservative strategy and clinical outcomes}

Out of the patients treated with ConS in district and regional hospitals 11 (3.3\%) patients died, 85 (25.4\%) were

Table 2. Criteria of qualification for conservative strategy

Tabela 2. Kryteria kwalifikacji do strategii zachowawczej

\begin{tabular}{lc} 
Criterion & \\
\hline TIMI risk score $(\leq 4)[\%(n / N)]$ & $88.0(295 / 335)$ \\
1 & $5.1(17 / 335)$ \\
2 & $35.5(119 / 335)$ \\
3 & $32.2(108 / 335)$ \\
4 & $15.2(51 / 335)$ \\
\hline No consent for invasive treatment $[\%(n / N)]$ & $3.9(13 / 335)$ \\
\hline Pulmonary oedema $[\%(n / N)]$ & $3.0(10 / 335)$ \\
\hline Cardiac arrest with neurological signs of CNS & $2.1(7 / 335)$ \\
damage [\% $(n / N)]$ & \\
\hline No arterial access [\% $(n / N)]$ & $1.2(4 / 335)$ \\
\hline Unknown reason $[\%(n / N)]$ & $1.8(6 / 335)$ \\
\hline CNS - central nervous system & \\
CNS - ośrodkowy uktad nerwowy
\end{tabular}

referred directly to the local catheterization laboratory and the remaining 239 (71.3\%) were discharged home, out of whom 20 (6.0\%) had a planned hospitalization appointment for elective coronary angiography within 3 months from the discharge date (tab. 4). In the group of 85 subjects primarily qualified for ConS, but transferred for delayed invasive diagnostics to a catheterization laboratory, 7 patients died, of whom 6 died due to the development of heart failure. Following discharge from the hospital, but before the 30 days of follow-up, 2 additional deaths were reported. Overall in-hospital mortality rate in the ConS group was $5.4 \%$, and 30-day mortality $6.0 \%$ (fig. 1).

In NSTACS patients qualified to receive InvS, 9 (4.7\%) cases of in-hospital death were noted, 5 of those due to the rapid development of cardiogenic shock; 121 (63.4\%) InvS patients after initial invasive treatment were transferred to other wards and departments in local and district hospitals for continuation of subsequent treatment; and 61 (31.9\%) InvS subjects were directly discharged home in good condition when reconvalescence had been completed (tab. 4). Out of 121 patients transferred to other hospitals, 9 patients died. Between discharge home and within the 30 days of follow-up, another 2 deaths were

Table 3. Antiplatelet and anticoagulant therapy

Tabela 3. Leczenie przeciwptytkowe i przeciwzakrzepowe

\begin{tabular}{lccc} 
& InvS & Cons & $p$ \\
\hline Acetylsalicylic acid $[\%(n / N)]$ & $97.9(187 / 191)$ & $98.5(325 / 330)$ & NS \\
\hline Clopidogrel/ticlopidine $[\%(n / N)]$ & $91.4(172 / 188)$ & $34.5(114 / 330)$ & $<0.0001$ \\
\hline Abciximab $[\%(n / N)]$ & $7.9(15 / 189)$ & 0 & - \\
\hline Eptifibatide $[\%(n / N)]$ & $2.6(5 / 189)$ & 0 & - \\
\hline Unfractionated heparin $[\%(n / N)]$ & $70.6(132 / 187)$ & $77.6(256 / 330)$ & NS \\
\hline Low molecular weight heparin $[\%(n / N)]$ & $24.6(46 / 187)$ & $8.8(29 / 330)$ & 0.0001
\end{tabular}

InvS - invasive strategy, ConS - conservative strategy

InvS - strategia inwazyjna, ConS - strategia zachowawcza

Table 4. 30-day clinical outcome

Tabela 4. Obserwacja 30-dniowa

\begin{tabular}{|c|c|c|}
\hline \multirow{6}{*}{$\begin{array}{l}\text { InvS } \\
N=191\end{array}$} & Hospitalization duration [day, mean \pm SD] & $4.5 \pm 3.2$ \\
\hline & Symptoms of heart failure (Killip class 2-4), $n$ (\%) & $7(3.7)$ \\
\hline & Transfer to other ward, $n(\%)$ & $121(63.4)$ \\
\hline & Discharge home, $n(\%)$ & $61(31.9)$ \\
\hline & In-hospital mortality, n (\%) & $18(9.4)$ \\
\hline & 30-day mortality, n (\%) & $20(10.5)$ \\
\hline \multirow{7}{*}{$\begin{array}{l}\text { Cons } \\
N=335\end{array}$} & Hospitalization duration [day, mean \pm SD] & $9.1 \pm 6.1$ \\
\hline & Symptoms of heart failure (Killip class 2-4), $n$ (\%) & $27(8.1)$ \\
\hline & Transfer to catheterization laboratory, $n(\%)$ & $85(25.4)$ \\
\hline & Discharge home, $n(\%)$ & $239(71.3)$ \\
\hline & including those patients with planned coronary angiography within 3 months from discharge date & $20(6.0)$ \\
\hline & In-hospital mortality, $n$ (\%) & $18(5.4)$ \\
\hline & 30-day mortality, n (\%) & $20(6.0)$ \\
\hline
\end{tabular}

InvS - invasive strategy, ConS - conservative strategy

InvS - strategia inwazyjna, ConS - strategia zachowawcza 


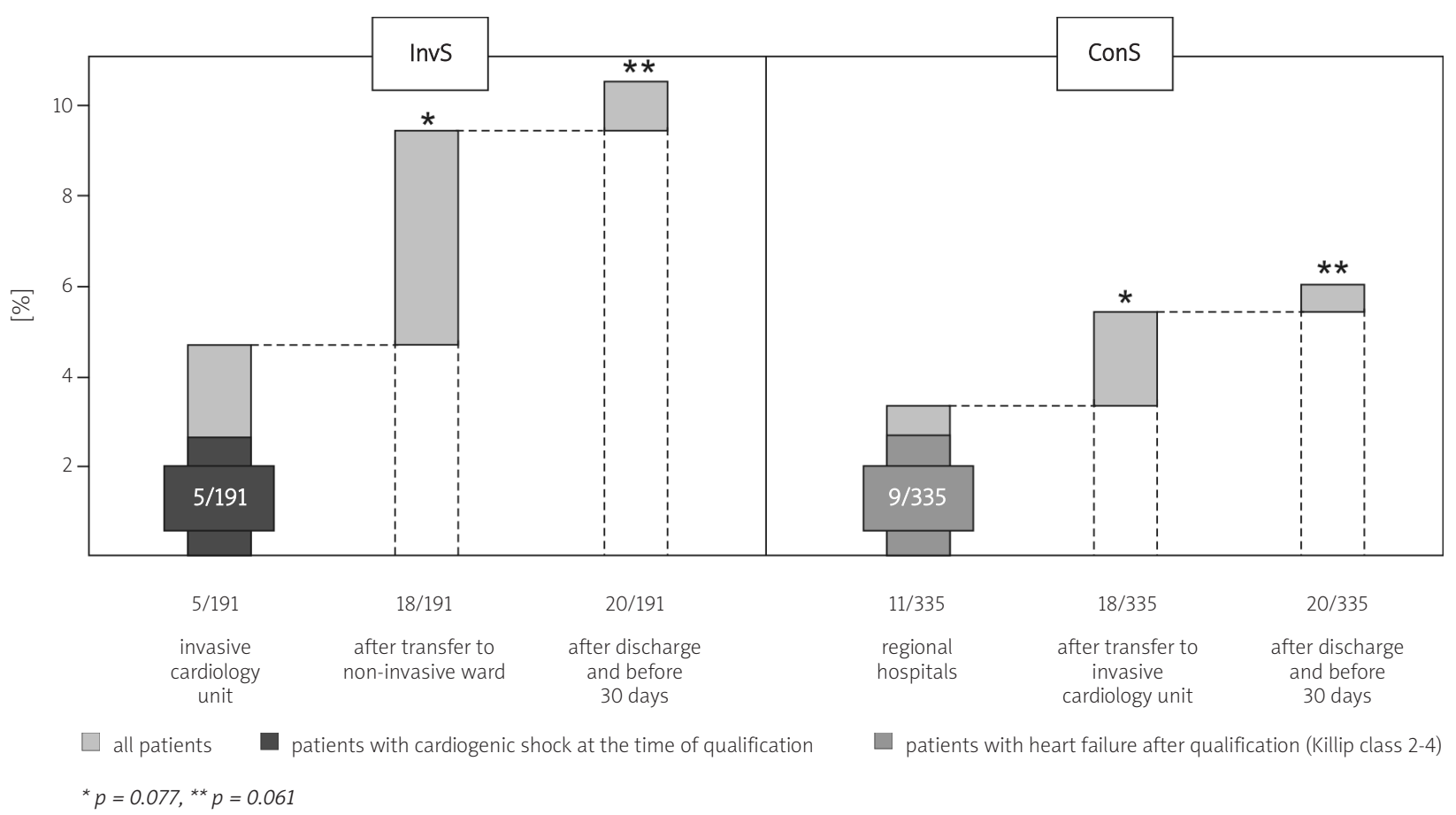

Fig. 1. 30-day mortality

InvS - invasive strategy, ConS - conservative strategy

Ryc. 1. Śmiertelność 30-dniowa

InvS - strategia inwazyjna, ConS - strategia zachowawcza

reported. In-hospital mortality was estimated and reached 9.4\%, whereas 30-day mortality was at the level of $10.5 \%$ and tended to be higher $(p=0.061)$ than that observed in the ConS group (fig. 1). In NSTACS patients without cardiogenic shock treated invasively 30-day mortality reached $7.9 \%$ ( $p=0.40$ vs. Cons).

The mean time of in-hospital stay completed with home discharge in the ConS group was significantly longer than in the case of the InvS group (mean 9.1 vs. 4.5 days, $p<0.0001$ ) (tab. 4). Symptoms of heart failure in Killip class $2-4$ developed in 27 (8.1\%) patients from the Cons and in $7(3.7 \%)$ from the InvS group $(p=0.049)$.

Statistical interactions between the applied strategy and symptoms of cardiogenic shock at the time of consultation, and also between implemented management and the development of heart failure after consultation were found. In the InvS group symptoms of cardiogenic shock on admission and in the ConS group symptoms of heart failure during the hospitalization period were independently correlated with the 30-day mortality rate (c-statistic 0.70, tab. 5).

\section{Discussion}

This retrospective study demonstrates that the use of guidelines for the management of NSTACS since 2005 has been associated with a trend toward lower 30-day mortality in patients treated conservatively without an initial invasive coronary approach. However, importantly, this group of patients was characterized by a lower risk of cardiovascular adverse events, in comparison with those qualified to receive invasive treatment. The aim of our study was not only to evaluate early clinical outcomes but also to identify potential predictors and risk factors of unfavourable clinical outcomes in NSTACS patients. Clinical algorithms used for risk stratification and optimization of therapy are based on sub-analyses of large controlled trials with clearly defined inclusion and exclusion criteria resulting in a careful selection of patients for the study. Therefore they do not necessarily reflect questions needed to be answered in everyday clinical practice.

In our NSTACS population allocation to the two therapeutic groups was based on risk estimation with the TRS [8]. Nearly in $90 \%$ of patients with NSTACS qualified for an early conservative strategy the overall risk did not exceed 4 points in the TRS. Originally the TRS system was based on treatment outcomes observed in patients with NSTACS from the TIMI11B clinical trial [12]. The predictive value of the scoring system was later verified in the TIMI11B and ESSENCE trials [12, 13]. A score of four points in the TRS indicates that overall risk of combined endpoint (defined as death, re-infarction and the need of urgent revascularization) is below $12 \%$ within 14 days of follow-up. For patients with 5 and 6-7 points in the TRS the risk was $26.2 \%$ and $40.9 \%$, respectively. There are several possible reasons why accuracy and predictive value of the TRS in our population could be different from those observed in 
Table 5. Independent predictors of death within 30 days

Tabela 5. Niezależne czynniki ryzyka wystapienia zgonu w ciagu 30 dni

\begin{tabular}{|c|c|c|c|}
\hline \multirow[t]{2}{*}{ Independent variable } & \multicolumn{3}{|c|}{ 30-day mortality } \\
\hline & OR & $95 \% \mathrm{Cl}$ & $p$ \\
\hline $\begin{array}{l}\text { Interaction of symptoms of cardiogenic shock at the time of consultation with } \\
\text { applied treatment strategy }\end{array}$ & & & $<0.0001$ \\
\hline InvS (shock vs. non-shock) & 49.5 & $12.5-234.2$ & \\
\hline $\begin{array}{l}\text { Interaction of symptoms of heart failure (Killip class 2-4) after consultation with } \\
\text { applied treatment strategy }\end{array}$ & & & 0.003 \\
\hline InvS (HF vs. non-HF) & 1.14 & $0.35-2.43$ & \\
\hline Cons (HF vs. non-HF) & 27.4 & $4.8-155.2$ & \\
\hline Treatment strategy (InvS vs. ConS) & 1.65 & $0.98-3.17$ & 0.09 \\
\hline Age (per year) & 1.06 & $0.99-1.14$ & 0.12 \\
\hline Clopidogrel/ticlopidine (Y/N) & 0.85 & $0.72-1.09$ & 0.15 \\
\hline Diabetes mellitus $(\mathrm{Y} / \mathrm{N})$ & 0.97 & $0.73-1.26$ & 0.50 \\
\hline Previous myocardial infarction $(\mathrm{Y} / \mathrm{N})$ & 1.59 & $0.41-6.19$ & 0.51 \\
\hline Gender (M vs. F) & 0.62 & $0.16-2.44$ & 0.84 \\
\hline GP IIb/IIla receptor antagonist $(\mathrm{Y} / \mathrm{N})$ & 0.97 & $0.88-1.13$ & 0.89 \\
\hline
\end{tabular}

the reference population of large clinical trials. First of all, the TIMI11B trial was dedicated to a conservative treatment strategy of NSTACS, and a planned invasive approach was one of the exclusion criteria. Secondly, there was a different distribution of patients with predefined levels of risk according to estimated TRS in our and reference population. The percentage of patients with TRS $\leq 4$ in the TIMI11B population was $83 \%$, and in our retrospective study only $56 \%$. This indicates that our NSTACS population was characterized by a primarily higher risk. Despite these differences, the risk stratification strategy based on the TRS used in 2005 resulted in quite good 30-day survival in unselected, consecutive patients with NSTACS qualified for ConS. Interestingly, patients with NSTACS in the InvS group were at much higher risk of cardiovascular adverse events according to the TRS than those in the ConS group, and considering the results of previous studies the mortality rate observed in that group could be much higher [14]. Although a trend toward higher mortality was observed in the InvS group with NSTACS, it was still comparable to that reported in the Cons group if only subjects without cardiogenic shock were taken into account. It is noteworthy that the duration of primary hospitalization to discharge was two-fold shorter in patients with InvS. Also the use of antiplatelet agents must have had an impact on the observed outcomes, especially in the Cons group, where ticlopidine derivatives were used less widely. Clinical trials completed after 2005 provided strong evidence for routine use of these medications in ACS [1, 2].

Our study indicates that the main cause of poor prognosis in NSTACS patients treated conservatively, as in STEMI subjects without coronary intervention [15], was the development of acute heart failure secondary to ACS. In the
InvS group the rate of heart failure symptoms was significantly lower. Our retrospective study also showed a low rate of early (about $25 \%$ ) and planned within 3 months after hospital discharge $(6 \%)$ invasive diagnostics in patients primarily qualified to receive ConS. A meta-analysis of clinical trials dedicated to ACS showed that relative mortality reduction between subjects receiving invasive and conservative treatment was parallel to the difference between the percentage of patients receiving invasive treatment in both primary InvS and ConS groups [16].

The use of the TRS for early risk stratification of patients with NSTACS resulted in a good short-term outcome in our study. Nevertheless, based on the observation of STEMI patients disqualified from InvS, it can be speculated that reconsideration of an invasive approach as a treatment option may be beneficial at every stage of hospitalization when acute heart failure symptoms occur.

\section{Study limitations}

Our study has several limitations, already described for patients with STEMI [15]. First, it is a retrospective analysis of clinical consequences of risk stratification and a decision making algorithm used in the management of patients with NSTACS in 2005. Second, despite our efforts, we failed to collect data for about $35(6.7 \%)$ patients in the conservative treatment group. Third, due to differences in defining ischaemia recurrence and reinfarction between centres and the lack of an objective tool for retrospective clarification of these states, our study did not analyse either recurrent myocardial ischaemia or reinfarction in the conservative strategy group. Furthermore, we did not perform any coronary angiographic analysis in patients 
from the conservative strategy group referred for delayed coronary angiography in other catheterization laboratories, due to the inability to collect a sufficient amount of angiographic data, although in our opinion such an analysis would provide additional and important information and a new insight into the analysed problem.

\section{Conclusions}

In NSTACS patients, low risk of complications at baseline was the main reason for disqualification from InvS. The mortality rate within 30 days did not differ significantly between therapeutic groups. Symptoms of heart failure during hospitalization were an independent predictor of death within 30 days in NSTACS patients treated conservatively.

\section{Acknowledgements}

The authors would like to thank the heads of cardiology departments of hospitals in Krakow (J. Dietl Hospital, G. Narutowicz Hospital, S. Żeromski Hospital, L. Rydygier Hospital, MSWiA Hospital, Military Hospital), the Department of Intensive Care of the $1^{\text {st }}$ Chair of General Medicine of the Jagiellonian University in Krakow, and also departments of cardiology and general medicine of hospitals in Brzesko, Bochnia, Chrzanow, Limanowa, Miechów, Myślenice, Nowy Targ, Olkusz, Oświęcim, Proszowice, Rabka, Sucha Beskidzka and Wadowice for their help in data collection of patients treated conservatively. The authors of this paper would like to address special thanks to Ms Katarzyna Latała for her help and contribution in follow-up data collection from the Lesser Poland Voivodal Registry of Citizens. Dr Zalewski was supported by a grant from the Foundation for Polish Science for both papers concerning conservative strategy in patients with STEMI and NSTACS.

\section{References}

1. Van de Werf F, Bax J, Betriu A, et al. Management of acute myocardial infarction in patients presenting with persistent ST-segment elevation. Eur Heart J 2008; 29: 2909-2945.

2. Bassand J-P, Hamm CW, Ardissino D, et al. Guidelines for the diagnosis and treatment of non-ST-segment elevation acute coronary syndromes. Eur Heart J 2007; 28: 1598-1660.
3. Savonitto S, Ardissino D, Granger CB, et al. Prognostic value of the admission electrocardiogram in acute coronary syndromes. JAMA 1999; 281: 707-713.

4. Volmink JA, Newton JN, Hicks NR, et al. Coronary event and case fatality rates in an English population: results of the Oxford myocardial infarction incidence study. The Oxford Myocardial Infarction Incidence Study Group. Heart 1998; 80: 40-44.

5. Terkelsen CJ, Lassen JF, Norgaard BL, et al. Mortality rates in patients with ST-elevation vs. non-ST-elevation acute myocardial infarction: observations from an unselected cohort. Eur Heart J 2005; 26: 18-26.

6. Fox KA, Dabbous OH, Goldberg RJ, et al. Prediction of risk of death and myocardial infarction in the six months after presentation with acute coronary syndrome: prospective multinational observational study (GRACE). BMJ 2006; 333: 1079-1080.

7. de Araujo Goncalves P, Ferreira J, Aguiar C, Seabra-Gomes R. TIMI, PURSUIT, and GRACE risk scores: sustained prognostic value and interaction with revascularization in NSTE-ACS. Eur Heart J 2005; 26: 865-872.

8. Antman EM, Cohen M, Bernink PJ, et al. The TIMI risk score for unstable angina/non-ST elevation MI: a method for prognostication and therapeutic decision making. JAMA 2000; 284: 835-842.

9. Granger CB, Goldberg RJ, Dabbous O, et al. Predictors of hospital mortality in the global registry of acute coronary events. Arch Intern Med 2003; 163: 2345-2353.

10. Van de Werf F, Ardissino D, Betriu A, et al. Management of acute myocardial infarction in patients presenting with ST-segment elevation. Eur Heart J 2003; 24: 28-66.

11. Bertrand ME, Simoons ML, Fox K, et al. Management of acute coronary syndromes in patients presenting without persistent ST-segment elevation. Eur Heart J 2002; 23: 1809-1840.

12. Antman EM, McCabe $\mathrm{CH}$, Gurfinkel EP, et al. Enoxaparin prevents death and cardiac ischemic events in unstable angina/non-Q-wave myocardial infarction: results of the thrombolysis in myocardial infarction (TIMI) 11B trial. Circulation 1999; 100: 1593-1601.

13. Cohen M, Demers C, Gurfinkel EP, at al. A comparison of lowmolecular-weight heparin with unfractionated heparin for unstable coronary artery disease. N Engl J Med 1997; 337: 447-452.

14. Bavry AA, Kumbhani DJ, Rassi AN, Bhatt DL, Askari AT. Benefit of early invasive therapy in acute coronary syndromes: a metaanalysis of contemporary randomized clinical trials. J Am Coll Cardiol 2006; 48: 1319-1325.

15. Zalewski J, Nycz K, Przewlocki T, et al. Conservative strategy in patients with ST-segment elevation myocardial infarction. Post Kardiol Interw 2010; 6: 97-103.

16. Cannon CP. Revascularisation for everyone? Eur Heart J 2004; 25 : 1471-1472. 